Modern Asian Studies 33, 2 (1999), pp. 383-403. (C) 1999 Cambridge University Press Printed in the United Kingdom

\title{
Tax Remission and Tax Burden in Rural Lower Burma during the Economic Crisis of the Early I93os
}

IAN BROWN

School of Oriental and African Studies, London

In the late 1970 s, a modest scholarly clash took place between James C. Scott and Michael Adas over the extent to which, if at all, the British administration in Burma had granted tax remissions to the rural population of the province during the economic crisis of the early 193os. This formed an important part of their wider debate on the causes of the major rebellion-the Hsaya San rebellionwhich erupted in Lower Burma in the closing days of 1930. First into the arena was Scott, in The Moral Economy of the Peasant: Rebellion and Subsistence in Southeast Asia, published in 1976. On this issue, Scott's starting point was the observation that the colonial world of the late nineteenth and early twentieth centuries saw a very marked increase in the capacity of the state to extract tax revenues from rural populations. The decisive strength of colonial administrations in this respect lay in paperwork, in 'the inexorable progress of cadastral surveys, settlement reports for land revenue, censuses, the issuance of land titles and licenses, identity cards, tax rolls and receipts ...', in other words, in the creation of 'nets of finer and finer official weave" that trapped rural taxpayers with increasing thoroughness. The creation of ever-finer fiscal nets was simply part, although an important part, of a great expansion in the administrative apparatus of colonial government in the late nineteenth and early twentieth centuries, as, in addition, it undertook the creation of centralized structures of local administration, the construction of railways, roads, and irrigation works, and the delivery of education, health, and

Research in the National Archives of India in New Delhi was made possible by generous financial support from the Nuffield Foundation and the British Academy South-East Asia Committee, and was greatly facilitated by the assistance of Ms Shruti Kapila.

${ }^{1}$ James C. Scott, The Moral Economy of the Peasant: Rebellion and Subsistence in Southeast Asia (New Haven: Yale University Press, 1976), p. 94.

oo26-749X/99/\$7.50+\$o.10 
public order. But of course, that expansion required ever-larger revenues. Here, therefore, was a neat twist. By this period, the very size of the state apparatus made it possible for colonial government to enforce tax demands on rural populations with far greater thoroughness: but at the same time, made it imperative that it actually did so. With escalating administrative costs, notably burgeoning public payrolls, the colonial state simply could not afford to be lenient with rural taxpayers.

This harsh reality was fully evident, suggested Scott, in Burma in the inter-war years. Remission of the capitation tax and the land revenue was, he argued, 'comparatively rare' and, when granted, 'seldom more than a small percentage of the loss in crops or income'. ${ }^{2}$ This was so even when, or perhaps particularly when, the price of paddy collapsed during the depression, in effect tripling the real burden of the capitation tax and the land revenue: desperate to stabilize its income during the economic crisis, the British administration had no choice but ruthlessly to enforce its tax demands. Scott focused on the capitation tax, because, in his view, it was the capitation tax-or rather the refusal of the colonial authorities to grant remissions on it during the depression crisis- 'which provided the detonator' for the Hsaya San rebellion. ${ }^{3}$ He pointed out that among the rural population of Lower Burma, the capitation tax was 'a unifying issue par excellence ... [Whether] smallholders, tenants, or laborers, the capitation tax was the single material claim that weighed on all of them at a given, regular time'. ${ }^{4}$ Moreover, that in raising the rural delta to rebellion, Hsaya San and his lieutenants constantly urged resistance to government collection of the tax; that a central feature of the millenarian vision propounded by Hsaya San was of a world without taxes; and, crucially, that the rebellion had erupted, in Tharrawaddy District, on 22 December 1930, just nine days before collection of the capitation tax was due, and one day

\footnotetext{
${ }^{2}$ Ibid. Scott's supporting reference for this important assertion is somewhat baffling. His source is the Report of the Committee Appointed to Examine the Land Revenue System of Burma, Rangoon: Government Printing, 1922, 2 volumes. But his page references are not to the report itself (volume I) but to the written evidence taken by the committee (volume II). The first reference (p. 4), the evidence of W. E. Lowry, the Financial Commissioner, makes no mention of remissions. The second (pp. 233, et seq.) reproduces passages relating to remissions from the annual Report on the Land Revenue Administration of Burma, covering almost all the 1910 , which, it seems to me, show frequent and extensive remissions.

${ }^{3}$ Ibid., p. ${ }^{1} 5^{1}$.

${ }^{4}$ Ibid., p. 155 .
} 
after cultivators in Tharrawaddy had had a petition for reduction or postponement of the tax rejected by the acting governor, no less. ${ }^{5}$

The dismissal of Scott by Michael Adas came in the latter's Prophets of Rebellion: Millenarian Protest Movements against the European Colonial Order, published in 1979. Perhaps surprisingly he focused on remission of the land revenue, while Scott, of course, had concentrated on the capitation tax. Adas argued that the land revenue system which the British had put in place in Burma, far from being brutally rigid, was markedly responsive to the cultivator's circumstances. The revenue was calculated as a percentage of the net output of the cultivator's land that was adjusted for differences in, for example, soil type and water conditions. The revenue demand was varied annually, the assessment in Lower Burma being based on the number of acres cultivated. Local officials had considerable discretion: 'After years in the field many district officers became quite sensitive to variations in local conditions and adjusted revenue demands accordingly. ${ }^{6}$ But, crucially, in addition to that structural flexibility, and in flat contradiction to Scott's assertions, 'hundreds of thousands of rupees in land revenue remissions [were] granted by the Government of Burma all through the years of the Depression-remissions that were given despite falling revenue returns. ${ }^{7}$

The principal aim of this paper is to settle this clash of views. During the 1930 s depression crisis, did the British administration in Burma grant unusual remissions of land revenue and the capitation tax: and if so, at what point in time were the remissions made (this may be an important consideration when examining the causes of the Hsaya San rebellion), and what scale of relief did they provide for the cultivators of the rice delta during those difficult years?

The land revenue was very important for the Burma administration. Of the total revenue at the disposal of the provincial government in $1926 / 27$, to select a pre-depression year almost at random, just over

${ }^{5}$ Ibid., pp. ${ }^{1} 53-5$.

${ }^{6}$ Michael Adas, Prophets of Rebellion: Millenarian Protest Movements against the European Colonial Order (Chapel Hill: University of North Carolina Press, 1979), p. 201, fn. 94. The book was republished by Cambridge University Press in 1987.

Ibid. Emphasis in original. 
31 per cent came from the land revenue. ${ }^{8}$ The foundation of land revenue administration in Burma was the settlement inquiry undertaken in each district of the province in rough sequence over a twenty to thirty year cycle. ${ }^{9}$ Involving highly detailed surveys and investigations-that commonly took around two years-the settlement inquiry determined the land revenue rate for every agricultural holding in that district. The revenue settlement, in various forms, was of course the foundation of land revenue administration across British India. But while in some Indian provinces, notably Bombay, the revenue demand on a holding as fixed at settlement ordinarily remained unchanged year after year for as long as the settlement was in force, regardless of annual variations in the holding's output, in the province of Burma, as Adas emphasized, the revenue demand was assessed each year to take account of fluctuations in production: in Lower Burma, where cultivation was relatively secure, the measure of a holding's production was the area under cultivation. Indeed, the Burma administration pointedly resisted pressure from the Government of India to abandon fluctuating for fixed assessment, despite the fact that the latter procedure would clearly have required considerably less resources. Moreover, again as noted by Adas, remission provisions in the province were quite generous. Ordinarily a cultivator was entitled to remission on the land revenue if he lost-for example through flood damage-one-third or more of his normal full crop, and the remission granted was proportional to the loss incurred. Revenue officials in the districts were given 'great power' in granting relief. ${ }^{10}$

The capitation tax was a much less important source of government revenue, in 1926/27 accounting for a little under six per cent of the total revenue at the disposal of the Government of Burma. ${ }^{11}$ It was imposed only in Lower Burma. ${ }^{12}$ It was levied on males between the

\footnotetext{
${ }^{8}$ Report on the Administration of Burma for the year I926-1927 (Rangoon: Government Printing and Stationery, 1928), pp. 9, 72. The proceeds from certain classes of revenue, including customs duty and income tax, were assigned to the Government of India.

${ }^{9}$ An excellent contemporary account of Burma's land revenue system can be found in J. S. Furnivall, An Introduction to the Political Economy of Burma (Rangoon: Burma Book Club, 1931), pp. 204-25. Furnivall, at one time Commissioner of Settlements and Land Records in Burma, had been chairman of a major official inquiry into this subject at the beginning of the 1920s: Report of the Committee Appointed to Examine the Land Revenue System of Burma.

${ }^{10}$ Furnivall, An Introduction to the Political Economy of Burma, p. 222.

${ }^{11}$ Report on the Administration of Burma for the year $1926-1927$, pp. 72-3.

12 Its counterpart in Upper Burma was the thathameda, 'a tax on income derived, whether by cultivators or non-cultivators, from non-agricultural sources': Furnivall,
} 
ages of eighteen and sixty, at the rate of Rs. 5 a year for a married man and Rs. 2-8 for a bachelor: ${ }^{13}$ presumably, therefore, it could be regarded as a tax on marriage! Certain groups were exempt-government officials, school teachers, and monks: interestingly, 'poverty' or 'no means of subsistence' was also a ground for exemption. The capitation tax was unpopular, hugely so of course with Burmese taxpayers and protest movements but also with many senior British officials, and a government committee was appointed in 1926 to consider whether alternative sources of revenue might be found. ${ }^{14}$ Perhaps the most powerful criticism was that the tax, by its very nature, was highly regressive: 'the man with an income of nine hundred rupees pays no more than the labourer with ninety'. ${ }^{15} \mathrm{~A}$ further major complaint was that the tax was collected between August and October, the months immediately before the harvest, when the agriculturist was particularly short of cash. Most therefore were forced to borrow in order to pay-which increased the agriculturist's tax burden, lined the pockets of the moneylender, while adding nothing to the government's income. An inquiry into the condition of agricultural tenants and labourers in the mid-1920s recommended that collection of the capitation tax take place between January and March, the date being varied by district and adjusted each year to reflect, for each locality, when the harvest was taken and therefore when the agriculturist had cash. ${ }^{16}$ Subsequently the date on which the tax became due was moved to 1 January. This was the position when the economic crisis hit Burma.

\section{II}

The crisis struck in 1930. Perhaps the most accurate, certainly the most visible indicator of turns in the economic fortunes of Lower Burma over the short term was the movement in rice prices. In the

op. cit., p. 202. Indeed the capitation tax was imposed in no other part of British India. It was justified in Lower Burma with the argument that no salt tax was levied in the province and that the rates of land tax there were low: Report of the Committee Appointed to Examine the Land Revenue System of Burma, vol. I, pp. 26-7.

${ }^{13}$ Report of the Capitation and Thathameda Taxes Enquiry Committee, 1926-27 (Rangoon: Government Printing and Stationery, 1927), p. 2.

${ }^{14}$ Ibid., p. 1.

${ }^{15}$ Report of the Committee Appointed to Examine the Land Revenue System of Burma, p. 127.

${ }^{6}$ T. Cooper, Report of Inquiry into the Condition of Agricultural Tenants and Labourers (Rangoon: Government Printing, 1924 [reprinted Rangoon: Central Press, 1966]), pp. 53-5. 
late 1920 , the year-on-year price of rice at Rangoon, comparing January with January, had fallen modestly. But 1930 opened with prices markedly down on the figures for January 1929. Prices rose a little over the middle months of the year-following the normal seasonal pattern-but then, from around September, plummeted. The wholesale price of White, Small Mills Specials, for example, fell 43 per cent between July 1930 and January $1931 .^{17}$

Not surprisingly, the early months of 1930 saw strong calls for lenient treatment of rural taxpayers. At the budget session of the Legislative Council, resolutions were passed recommending postponement of collection of the land revenue, which ordinarily began on 15 February, to June, and a substantial reduction in the rates levied. ${ }^{18}$ The government rejected these recommendations. It was by no means certain that any category of agriculturist would gain from postponement. No labourers and few tenants paid land revenue. The small owner-cultivator usually sold his crop immediately it was harvested, that is by February, and he should therefore be better placed to pay the land revenue on the due date, ${ }_{15}$ February, than later. Perhaps the large landowner might benefit from postponement, in that it could help him hold on to his crop until prices rose later in the season: on the other hand, given the current state of the rice market, it was impossible to be confident that prices would in fact rise in the coming months. But if it was extremely unlikely that the agriculturist would gain, at least in the government's view, there was no doubt that the government itself would lose: postponement of collection of the land revenue from February to June would turn a modest projected surplus in the government's finances for the financial year ending on 31 March 1930 into a large deficit. As for the call for a reduction in the rates of land revenue, the government pointed out that the Burma Settlement Instructions provided for reduction 'when a serious and not merely temporary fall occurs in the prices of [padi] below the normal prices assumed at settlement' ${ }^{19}$ Those circumstances had not yet arisen: despite recent falls, prices were still above those assumed at settlement in many districts.

As the rice price plunged over the final months of 1930 , the calls

${ }^{17}$ I have provided a fuller account of these price movements in 'The Economic Crisis and Rebellion in Rural Burma in the Early 1930s', in Ryoshin Minami, Kwan S. Kim, and Malcolm Falkus (eds), Growth, Distribution, and Political Change: Asia and the Wider World (Basingstoke: Macmillan, forthcoming).

${ }_{18}^{18}$ Rangoon Gazette Weekly Budget [henceforth RGWB], 10 March 1930, p. 25.

19 Ibid. 
for relief grew still stronger. In November, an organized meeting of over three thousand landowners, cultivators, rice millers, and moneylenders in Insein District called for collection of the land revenue to be moved to 30 June and for 'drastic cuts' in the rates. ${ }^{20}$ At around the same time, cultivators in Tharrawaddy petitioned the government for reduction or postponement of the capitation tax. Again the government refused to yield. As noted above, for James Scott the rejection of the Tharrawaddy petition, on 21 December, was important in precipitating the outbreak of the Hsaya San rebellion, the following day.

Less than two weeks after the outbreak of the rebellion, the government signalled a shift in its attitude, announcing in a press communiqué released on 2 January $193^{1}$ that it 'has had under consideration' a temporary reduction in land revenue rates in some districts. ${ }^{21}$ It is tempting to see in this the government being forced-even panicked-into greater leniency by the rebellion. But there are a number of considerations which might suggest otherwise. First, in the opening days of $193^{1}$ it would not have been evident that the disturbances which had just broken out in Tharrawaddyserious though they were-marked the beginning of a major rebellion. Indeed, as government forces had overrun the rebel headquarters on $3^{1}$ December 1930, there were grounds for believingbriefly - that the crisis had passed. In addition, at no point did the colonial administration accept - at least in public - that the rebellion had significant economic causes. The final published report on the rebellion argued that 'there is not a scintilla of evidence in support of the thesis ... that the rebellion ... was the spontaneous revolt of an ignorant peasantry impoverished by the slump in paddy prices and maddened by harsh taxation, that it was chiefly due to oppression on the part of tax collectors, and that it was precipitated by [the acting governor's rejection of the Tharrawaddy petition for reduction or postponement of the capitation tax] on the 21 st December 1930'. ${ }^{22}$ In view of this, it is difficult to argue that the administration's measures to reduce the tax burden on the cultivator were provoked-to any significant degree-by the outbreak of the rebellion. And finally, in one crucial respect the press communiqué issued on 2 January 1931 did not mark a change in the government's position. In March

${ }^{20}$ RGWB, 24 November 193o, p. 8.

${ }^{21} R G W B, 12$ January 1931, p. 18.

${ }^{22}$ The Origin and Causes of the Burma Rebellion (1930-32) (Rangoon: Government Printing and Stationery, 1934), p. 44. 
1930 it had rejected a call for a reduction in the rates of land revenue on the grounds that rice prices were still above those assumed at settlement. By the end of the year, for a number of districts, this was no longer the case. That in itself was sufficient to trigger a more lenient administration of the revenue.

The reductions, remissions, and postponements granted from the beginning of 1931 were as follows. With respect to the land revenue, at the beginning of 1931 itself, the administration took three measures. It reduced the rate in fifteen districts where the price of the main crop was now below the price assumed when the district was last settled. ${ }^{23}$ Only three of the districts-Myaungmya, Maubin, and Pyapôn-were in the rice delta. For each district the size of the reduction was determined by the difference between the current crop price and the price assumed at settlement, ${ }^{24}$ and ranged from onethird to one-tenth. Second, the administration put back the date on which collection of the land revenue would begin, from ${ }_{15}$ February to 7 March, to give the cultivator more time to sell his crop. ${ }^{25}$ And finally, district officers were given discretion to remit land revenue in those cases where they were satisfied that there was a genuine inability to pay, and instructed to resort to the sale of land to recover arrears of revenue only where necessary 'to meet contumacious default ${ }^{26}$ In the following year, 1931/32, that is the land revenue administration year which ended on 30 June 1932, the government repeated the rate reductions in the fifteen districts: in addition it appointed 'an exceptionally large number of special remission officers'. ${ }^{27}$ In 1932/33, rice prices were considerably down, and consequently, for the first time, the administration reduced land revenue rates throughout the rice delta-by one-seventh or oneeighth. $^{28}$ Rice prices went lower still in 1933/34, and the administration responded by further reducing land revenue rates in the delta districts and by urging district officers 'to show all possible

\footnotetext{
${ }^{23}$ Report on the Land Revenue Administration of Burma [henceforth RLRAB], During the Year ended the 3oth June I93 I [henceforth I93O/3I] (Rangoon: Government Printing and Stationery, 1932), pp. 4-5.

${ }^{24}$ This was the formula reported in Chief Secretary, Home and Political Department, Government of Burma to the Secretary to the Government of India, Home Department, 6 February 1933. National Archives of India, New Delhi [henceforth NAI], Home, Political, 7/3, 1933.

${ }^{25} R G W B$, 9 February 1931 , p. 1.

${ }^{26} R G W B, 25$ May 1931, p. 20.

${ }^{27}$ RLRAB, I93I/32, pp. 4-5, 7, 17 .

${ }^{28} \operatorname{RLRAB}, \mathrm{I} 932 / 33, \mathrm{p} .5$.
} 
consideration to assessees who [are] really unable to pay promptly'. ${ }^{29}$ In 1934/35, prices were slightly up, and this triggered a smaller reduction in land revenue rates: for example, in Irrawaddy Division, the reduction, one-fifth in $1933 / 34$, was now one-sixth. ${ }^{30}$

With respect to the capitation tax, at the beginning of 1931 , district officers involved in its collection were instructed 'to avoid unduly harassing' assessees, and 'to exercise careful discretion' before initiating legal proceedings in cases of non-payment. ${ }^{31}$ But for that year-the year which would end on 3oJune 1931-there was no reduction in the rates of capitation tax. However, for the following year, 1931/32, there was a reduction of one-quarter. ${ }^{32}$ For the three subsequent years, the reduction was slightly less-one-fifth. ${ }^{33}$ And in $1935 / 36$, with economic conditions clearly improved, the reduction was one-tenth. ${ }^{34} \mathrm{But}$, as noted earlier, the capitation tax had long been strongly disliked by both the Burmese taxpayer and many senior British officials, and in 1937 the administration announced its gradual abolition, beginning with a two-fifths reduction in the rates for $1937 / 38 .^{35}$ The capitation tax would be collected for the final time in 1940/41.

Some insight into the impact of these measures on the administration of the revenue in the rice delta is provided by the figures for demand, remissions, collections, and outstandings published annually by the government in its Report on the Land Revenue Administration of Burma. The figures for the land revenue in three major delta districts-Tharrawaddy, Hanthawaddy, and Pegu-in the late 1920 s and early 1930 are given in Tables 1, 2 and 3 . In all three districts there was a considerable reduction in the land revenue demandfrom 1931/32 in Tharrawaddy, from 1932/33 in Hanthawaddy and in Pegu. In part, of course, this reflected the reductions in land revenue rates, applied throughout the rice delta from the administra-

${ }^{29}$ RLRAB, I933/34, pp. 5-6, 8-9.

${ }^{30} R L R A B, \quad 1934 / 35$, pp. $4^{-6}$. No fractional reduction was necessary in Hanthawaddy District, as revised land revenue rates, that would reduce the revenue demand by some six lakh, were introduced in 1934/35 following a new settlement of the district.

31 Secretary to the Government of Burma, Revenue Department to the Secretary to the Government of India, Home Department, 23 January 1931. NAI, Home, Political, 77/31, 1931, A.

${ }^{32}$ RLRAB, I93I/32, p. 9 .

${ }_{33} R L R A B, I 932 / 33$, p. 10; RLRAB, I933/34, p. 10; RLRAB, I934/35, p. 9

${ }^{34}$ RLRAB, I935/36, p. 8.

${ }_{35} R L R A B$, I936/37, p. 7; Ronald M. J. Harris, 'Intended Abolition of the Capitation and Thathameda Taxes: Genesis of the Question', 17 June 1937. India Office Collections, L/F/7/343. 
TABLE 1

Land Revenue in Tharrawaddy District, I926/27-1934/35 (in rupees)

\begin{tabular}{|c|c|c|c|c|}
\hline Year & Demand & Remissions & Collections & Outstandings \\
\hline $1926 / 27$ & $1,658,994$ & $3^{6,978[2.2]}$ & $\begin{array}{l}1,588,65^{2} \\
{[95.8]}\end{array}$ & $33,364[2.0]$ \\
\hline $1927 / 28$ & $1,597,176$ & $33,890[2.1]$ & $\begin{array}{l}1,546,065 \\
{[96.8]}\end{array}$ & $17,221[1.1]$ \\
\hline $1928 / 29$ & $1,619,180$ & $4^{1,199}[2.5]$ & $\begin{array}{l}1,5^{62,45^{8}} \\
{\left[9^{6.5}\right]}\end{array}$ & $15,5^{23}[1.0]$ \\
\hline $1929 / 30$ & $1,668,530$ & $3,193[0.2]$ & $\begin{array}{l}1,661,659 \\
{[99.6]}\end{array}$ & $3,678[0.2]$ \\
\hline $193^{0} / 3^{1}$ & $1,660,671$ & $7,86_{3}[0.5]$ & $\begin{array}{l}1,396,05^{1} \\
{[84.0]}\end{array}$ & $25^{6,757[15.5]}$ \\
\hline $193^{1 / 32}$ & $1,5^{14}, 022$ & $15^{6,35^{6}[10.3]}$ & $\begin{array}{l}1,353,783 \\
{[89 \cdot 4]}\end{array}$ & $3,88_{3}[0.3]$ \\
\hline $193^{2 / 33}$ & $1,3^{84}, 917$ & 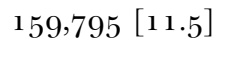 & $\begin{array}{l}1,222,357 \\
{[88.3]}\end{array}$ & $2,76_{5}[0.2]$ \\
\hline $1933 / 34$ & $1,3^{8} 3,993$ & $4,45^{2}[0.3]$ & $\begin{array}{l}1,371,233 \\
{[99.1]}\end{array}$ & $8,308[0.6]$ \\
\hline $1934 / 35$ & $1,402,160$ & $10,866[0.8]$ & $\begin{array}{l}1,390,892 \\
{[99.2]}\end{array}$ & $402[0.0]$ \\
\hline
\end{tabular}

Source: Report on the Land Revenue Administration of Burma. Rangoon: Government Printing and Stationery, annually.

Notes:

Land Revenue: excluding Irrigation Credits.

Demand: Original demand in assessment rolls.

Year: ending the 3 oth June. Thus $1926 / 27=1$ July 1926 to 30 June 1927 .

Figures in brackets: as percentage of revenue demand.

TABLE 2

Land Revenue in Hanthawaddy District, I926/27-1934/35 (in rupees)

\begin{tabular}{|c|c|c|c|c|}
\hline Year & Demand & Remissions & Collections & Outstandings \\
\hline $1926 / 27$ & $3,091,749$ & $81,5^{69}[2.6]$ & $2,986,636\left[9^{6.6}\right]$ & $23,544[0.8]$ \\
\hline $1927 / 28$ & $3,092,695$ & $85,766[2.8]$ & $3,003,102[97.1]$ & $3,827[0.1]$ \\
\hline $1928 / 29$ & $3,087,764$ & $159,637[5.2]$ & $2,928,127[94.8]$ & 0 \\
\hline $1929 / 3^{\circ}$ & $3,085,913$ & $99,5^{64}[3.2]$ & $2,986,3 \circ 6[96.8]$ & $43[$ o.o] \\
\hline $1930 / 31$ & $3,093,835$ & 28,655 [0.9] & $2,957,610[95.6]$ & $107,570[3.5]$ \\
\hline $1931 / 32$ & $2,993,636$ & $168,003[5.6]$ & $2,721,410[90.9]$ & $104,223[3.5]$ \\
\hline $1932 / 33$ & $2,65^{8,293}$ & $38,305[1.4]$ & $2,490,403[93 \cdot 7]$ & $129,5^{8} 5[4.9]$ \\
\hline $1933 / 34$ & $2,5^{23}, 094$ & $33,368[1.3]$ & $2,422,636[96.0]$ & $67,090[2.7]$ \\
\hline $1934 / 35$ & $2,369,860$ & $26,45^{1}[1.1]$ & $2,332,088[98.4]$ & $11,321[0.5]$ \\
\hline
\end{tabular}

Source and notes: as Table 1 . 
TAX IN RURAL LOWER BURMA, EARLY 193 OS

TABLE 3

Land Revenue in Pegu District, I92 6/ 27-1934/35 (in rupees)

\begin{tabular}{|c|c|c|c|c|}
\hline Year & Demand & Remissions & Collections & Outstandings \\
\hline $1926 / 27$ & $2,361,062$ & o & $\begin{array}{l}2,361,062 \\
{[100.0]}\end{array}$ & o \\
\hline $1927 / 28$ & $2,533,5^{28}$ & o & $\begin{array}{l}2,533,5^{28} \\
{[100.0]}\end{array}$ & o \\
\hline $1928 / 29$ & $2,549,098$ & o & $\begin{array}{l}2,549,098 \\
{[100.0]}\end{array}$ & o \\
\hline $1929 / 30$ & $2,497,94^{\circ}$ & o & $\begin{array}{l}2,497,94^{\circ} \\
{[100.0]}\end{array}$ & 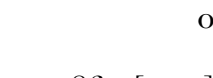 \\
\hline $1930 / 3^{1}$ & $2,367,359$ & $4,724[0.2]$ & $\begin{array}{l}2,002,771 \\
{[84.6]}\end{array}$ & $359,864[15.2]$ \\
\hline $193^{1 / 32}$ & $2,279,5^{62}$ & $379,732[16.6]$ & $\begin{array}{l}1,455,909 \\
{[63.9]}\end{array}$ & $443,921[19.5]$ \\
\hline $1932 / 33$ & $2,003,406$ & $15^{1,966[7.6]}$ & $\begin{array}{l}1,43^{6,929} \\
{[71.7]}\end{array}$ & $4^{14}, 5^{11}[20.7]$ \\
\hline 1933/34 & $1,912,984$ & $15^{0,4} 4^{18}[7 \cdot 9]$ & $\begin{array}{l}1,45^{6,642} \\
{[76.1]}\end{array}$ & $305,924[16.0]$ \\
\hline $1934 / 35$ & $1,924,368$ & $244,721\left[\begin{array}{ll}12.7\end{array}\right]$ & $\begin{array}{l}1,593,05^{\circ} \\
{[82.8]}\end{array}$ & $86,597[4 \cdot 5]$ \\
\hline
\end{tabular}

Source and notes: as Table 1.

tion year 1932/33. But at times it also reflected a decline in the area assessed for revenue. In 1931/32 there was a decline in every district in the Pegu and Irrawaddy Divisions-for a variety of reasons, many, but not all, arising from the economic crisis: failure of the late rains; floods; the disturbed condition of many districts because of the rebellion; the intimidation of cultivators who sought tenancies from Indian landowners; the seizure of holdings for non-payment of revenue in previous years; the abandonment of holdings because of the depression in the paddy market or difficulties in securing cultivation loans. ${ }^{36}$ As Adas would note, here was a clear demonstration of the benefit to the rural taxpayer of a system of land revenue administration that employed annual assessment to take account of year-byyear fluctuations in crop production.

But in other important respects there were considerable differences between the three districts. Tharrawaddy in the late 1920 s had a stable land revenue demand and low rates of remissions and outstandings (and thus a high collections rate). That pattern disintegrated in the administration year 1930/31. It seems clear that the fall in the price of rice in the final months of 1930 was too sudden and too great

${ }^{36}$ RLRAB, I93I/32, pp. 5-6. 
for the local administration to take action in the time available and reduce the revenue demand or increase remissions, and that consequently those who owned land protected themselves by defaulting on a substantial scale. Outstandings in that year soared to 15.5 per cent of the revenue demand. But in the following two years, 1931/32 and 1932/33, the administration in Tharrawaddy did respond by reducing the land revenue demand and by increasing remissions, the latter rising to 10.3 per cent and then 11.5 per cent of the demand. These measures appear to have been well-judged, for the rate of outstandings in those two years was extremely low. But of course the cost of reduced demand and increased remissions was a substantial fall in collections. At its lowest, in 1932/33, the income from the land revenue in Tharrawaddy District was just 73.6 per cent of its pre-crisis peak, which had been in 1929/30. In Hanthawaddy, the administration of the land revenue during the depression crisis was strikingly stable. Outstandings remained modest, while the rate of remissions, with the exception of a moderate leap in $193^{1 / 32}$, was in fact below that of the late 1920 . Thus relief for the Hanthawaddy landowners came with the substantial reduction in land revenue demand. The percentage fall in collections in the district was almost as great as that in Tharrawaddy.

In contrast, the administration of the land revenue in Pegu District appears to have been in disarray. In the four years 1926/27 to 1929/30, there had been no remissions and no outstandings. When the crisis struck, in the administration year 1930/31, landowners in Pegu, like those in Tharrawaddy, protected themselves by defaulting on a large scale. But unlike Tharrawaddy, in Pegu outstandings remained high over the following three years-no less than 20.7 per cent of the revenue demand in $1932 / 33$. At the same time, the local administration was reducing the revenue demand and granting substantial remissions-16.6 per cent of the demand in $193^{1 / 32}$. The result was a collapse in collections, far more serious than those taking place in Tharrawaddy and Hanthawaddy. In 1932/33 the income from the land revenue in Pegu District was a mere $5^{6.4}$ per cent of its 1928/29 level. With the evidence available, there is no obvious explanation for this outcome. It would be difficult to argue that cultivation conditions in Pegu were that different from those in Tharrawaddy and Hanthawaddy, or that the disruption to the administration of the land revenue arising from the Hsaya San rebellion was more severe there. Perhaps the most that can be said is that the soaring outstandings in Pegu-at or near one-fifth of the revenue demand in each of the four years beginning with 1930/31, and this 
TAX IN RURAL LOWER BURMA, EARLY 193 OS

TABLE 4

Capitation Tax in Tharrawaddy District, 1926/27-1934/35 (in rupees)

\begin{tabular}{llllr}
\hline Year & Demand & Remissions & Collections & Outstandings \\
\hline $1926 / 27$ & 432,992 & $25,917[6.0]$ & $403,544[93 \cdot 2]$ & $3,531[0.8]$ \\
$1927 / 28$ & 428,759 & $25,911[6.0]$ & $402,427[93 \cdot 9]$ & $421[0.1]$ \\
$1928 / 29$ & 436,604 & $17,473[4 \cdot 0]$ & $419,050[96.0]$ & $81[0.0]$ \\
$1929 / 30$ & 446,500 & $13,780[3.1]$ & $432,720[96.9]$ & 0 \\
$1930 / 31$ & 452,053 & $36,046[8.0]$ & $371,655[82.2]$ & $44,35^{2}[9 \cdot 8]$ \\
$1931 / 32$ & 320,055 & $17,405[5 \cdot 4]$ & $302,192[94 \cdot 5]$ & $45^{8}[0.1]$ \\
$1932 / 33$ & 340,241 & $29,674[8.7]$ & $310,567[91.3]$ & 0 \\
$1933 / 34$ & 342,690 & $22,133[6.5]$ & $320,557[93 \cdot 5]$ & 0 \\
$1934 / 35$ & 378,656 & $22,85^{1}[6.0]$ & $355,805[94.0]$ & 0 \\
\hline
\end{tabular}

Source: Report on the Land Revenue Administration of Burma. Rangoon: Government Printing and Stationery, annually.

Notes:

Year: ending the 3oth June. Thus $1926 / 27=1$ July 1926 to 3o June 1927 .

Figures in brackets: as percentage of tax demand.

despite the reductions in the demand and increased remissionswould suggest weaknesses within the Pegu administration itself, perhaps structural flaws or failure on the part of individuals. ${ }^{37}$

Turning to the administration of the capitation tax during the depression crisis, it is necessary to provide the figures for just two districts, simply because there was less variation across the rice delta. Given the pivotal position of the tax in James Scott's analysis of the causes of the Hsaya San rebellion, one of those districts must be Tharrawaddy - the site of the first outbreak.

TABLE 5

Capitation Tax in Insein District, I926/27-1934/35 (in rupees)

\begin{tabular}{llllr}
\hline Year & Demand & Remissions & Collections & \multicolumn{1}{c}{ Outstandings } \\
\hline $1926 / 27$ & 267,310 & $20,240[7.6]$ & $247,070[92.4]$ & o \\
$1927 / 28$ & 264,488 & $38,133[14 \cdot 4]$ & $226,355[85.6]$ & 0 \\
$1928 / 29$ & 267,238 & $25,991[9 \cdot 7]$ & $241,247[90.3]$ & 0 \\
$1929 / 30$ & 273,460 & $19,284[7.0]$ & $254,176[93 \cdot 0]$ & 0 \\
$1930 / 31$ & 269,192 & $48,097[17.8]$ & $217,940[81.0]$ & $3,155[1.2]$ \\
$1931 / 32$ & 189,519 & $11,842[6.2]$ & $154,044[81.3]$ & $23,633[12.5]$ \\
$1932 / 33$ & 197,680 & $19,068[9 \cdot 7]$ & $150,517[76.1]$ & $28,095[14.2]$ \\
$1933 / 34$ & 202,676 & $21,441[10.6]$ & $178,763[88.2]$ & $2,472[1.2]$ \\
$1934 / 35$ & 213,788 & $22,846[10.7]$ & $187,669[87.8]$ & $3,273[1.5]$ \\
\hline
\end{tabular}

Source and notes: as Table 4 .

\footnotetext{
${ }^{37}$ Some support for this view comes from the odd critical remark in the government's annual revenue report, although none, as far as I can see, was directed at
} 
In both Tharrawaddy and Insein-indeed in every district in Lower Burma-the most striking feature of the administration of the capitation tax during the depression crisis was the sharp reduction in the tax demand in the administration year 1931/32. The reduction was principally due, of course, to the cut in the capitation tax rateby one-quarter-agreed by the administration for that year. ${ }^{38}$ But it also reflected a fall in the numbers assessed for the tax. In the 1920 s the total number of assessees had risen by around 1.5 per cent each year, with the increase in population. ${ }^{39}$ But in the crisis year 1931/ 32 the total fell sharply, by almost 100,000 or over six per cent. And although it recovered within a few years, in individual districts-for example in Hanthawaddy and Pyapôn-the number of assessees in the mid-1930s was still substantially below that of the late $1920 .^{40}$ These reductions had several causes. The fall in the number assessed for the capitation tax in Tharrawaddy in 1931/32 was attributed to the rebellion, which had forced people to migrate to other districts in search of peace or work, and to the closure of a number of local rice mills by the trade crisis, which, again, had driven people from the area to look for work elsewhere. ${ }^{41}$ The fall in Pegu, Hanthawaddy, and Pyapôn Districts in the same year was explained by the hurried exodus of a large part of the Indian population in the face of serious communal violence, much of it fired by the rebellion. Interestingly, in Insein in the following year it was attributed in part to 'omissions by slack and inefficient headmen'. ${ }^{42}$

When the economic crisis struck with full force, in 1930/31, the administration in Tharrawaddy responded by increasing remissions on the capitation tax, to 8.o per cent of the demand. Even so, those liable for the tax were able to protect their position only by defaulting on a substantial scale: outstandings, which had been negligible in the immediately preceding years, leapt to 9.8 per cent of the tax demand in 1930/31. The major relief came with the cut in the tax rate in $1931 / 32$. That cut was sufficient, combined with a modest

the Pegu administration. For example, it was said of Thatôn District in 1930/31 that 'better results would have been produced if the problem [high outstandings] had been tackled with greater vigour at the outset and with adequate control from the district office': RLRAB, I930/3I, p. 7 .

38 The modest rise in the capitation tax demand the following year reflected a smaller cut in the rate-of one-fifth.

${ }^{39} R L R A B, I 933 / 34$, p. 10.

${ }^{40}$ RLRAB, I934/35, pp. 8-9.

${ }^{41} R L R A B, I 93 I / 32$, p. 9 .

42 RLRAB, I932/33, p. 9 . 
level of remissions, to ensure that outstandings were kept extremely low in 1931/32, and in the three subsequent years disappeared entirely. Of course, the cost to the administration was a substantial fall in collections. At its lowest, in 1931/32, the income from the capitation tax in Tharrawaddy District was just 69.8 per cent of its pre-crisis peak, which had been in 1929/30.

The administration of the capitation tax in Insein District was more volatile. In the crisis year 1930/31 there was an upsurge in remissions, to 17.8 per cent of the tax demand. When, in the following year, the tax rate was cut, the level of remissions was reduced: but perhaps too sharply, for outstandings then soared, to 14.2 per cent of the demand in 1932/33. The cut in the rate, moderate remissions, and high outstandings meant, of course, a collapse in collections. The income raised by the capitation tax in Insein in 1932/33 was only 59.2 per cent of the $1929 / 30$ figure.

\section{III}

To return to James Scott and Michael Adas. It must now be fully evident that James Scott's assertion-in its bald form-that through the depression years the British administration in Burma ruthlessly enforced its tax demands in the rice delta, does not stand. Rather, with both the land revenue and the capitation tax, the administration agreed substantial cuts in the rates and considerably enhanced remissions. And it did so at considerable cost to its own financial position. Comparing 1932/33 with 1929/30, the income from the land revenue in Pegu and Irrawaddy Divisions had fallen from Rs 20.0 million to Rs 15.0 million, a drop of 25.0 per cent, the income from the capitation tax in the same divisions, from Rs 3.6 million to Rs 2.5 million, a drop of 30.5 per cent. ${ }^{43}$

${ }^{43}$ RLRAB, I929/3o, pp. 35, 39; RLRAB, I932/33, pp. 27, 31. With the salaries and fixed allowances of its officials accounting for more than half of the government's expenditure from revenue, falls in the revenue on this scale clearly created major problems for the administration as an administration. From September 1931 new recruits to the service were appointed at the bottom point of the appropriate scale, on salaries cut by 15 per cent. In the following year the salaries of all officials were cut by 10 per cent, later reduced to 5 per cent. Interestingly, a retrenchment committee appointed in August 1933 and dominated by local businessmen questioned whether, in view of the substantial reduction in land revenue rates, 'the present system of land records and land revenue assessment is not more elaborate and expensive than the Province can afford and whether methods, at once simpler and more capable of automatic application, will not have to be devised': Report of the 
But in one crucial context, James Scott is on strong ground. It is also clear from the text and the tables above that the British administration took action-cutting tax rates and increasing remissions-not in anticipation of the onset of the economic crisis in the final months of 1930 but after, in some cases long after, it had struck the rice delta with full force. In the administration of the land revenue in Tharrawaddy, Hanthawaddy, and Pegu in the crisis year 1930/31, the revenue demand was held at roughly the level of the previous year and remissions were kept extremely low, so that in order to protect their position, landowners were forced to default on a substantial scale. It was not until the administration year 1932/33 that land revenue rates were reduced throughout the rice delta. There was no cut in the rates of capitation tax until the year 1931/ 32: and although in the previous year, the crisis year, the local administrations in Tharrawaddy and Insein-indeed in every district in Lower Burma-had substantially increased remissions, in most cases action had been taken only after 1 January 1931, when the tax came due. This argument can be put in another way, one which focuses on the central concern of James Scott and Michael Adas. The British administration in Burma cut tax rates and increased remissions after the outbreak of the Hsaya San rebellion in the last days of 1930. While it may well have been markedly flexible over the depression years as a whole, in the final weeks before that eruption-with rice prices plummeting - it was strict and unyielding.

The final issue-how much relief did the reductions in tax rates and the increased remissions provide for the cultivators in the rice delta during the depression years-is far more difficult to settle. The difficulty lies mainly in the fact that any effective consideration of this issue must seek to capture the considerable variations in experience-variations by place, time, and, crucially, by occupationamong the agriculturists of the Lower Burma delta. As is clear from the discussion and tables above, there were marked differences between districts in the administration of the land revenue and the capitation tax: cuts in land revenue rates during the depression years were determined district-by-district, while there was also considerable variation between districts in the levels of remission granted. But perhaps more importantly there were major differences-once 
again, in terms of the impact of rate cuts and remissions-as between the main categories of agriculturist. The landless labourer would clearly secure no direct benefit from a more lenient administration of the land revenue but, in terms of his financial position as a whole, would gain considerably more from a cut in the rate of capitation tax than would the major landowner. A modest reduction in land revenue rates might be crucial in securing the position of the marginal owner-cultivator but make little difference to those who owned hundreds of acres. Ideally, therefore, assessment of the impact of the reductions in tax rates and the increased remissions must specify place, time, and class-must be with reference to, say, the landless labourer in Tharrawaddy District in 1930/31. Unfortunately the primary data rarely yield that detail. In particular, the revenue statistics published by the colonial administration and used extensively in this paper, concerned as they are only with aggregates and averages, miss entirely the crucial perspective on distribution.

There is a further difficulty. Assessment of the impact of the administration's tax cuts and increased remissions on the agriculturist (on the main categories of agriculturist) requires some account of the agriculturist's overall financial position, for clearly the greater the share of tax payments in his expenditures, the greater the impact of a given measure of relief. There are numerous reports on, for example, the wages of agricultural labourers, cultivation costs, loan charges, scattered through government publications in the early 1930s. But the only systematic investigation of 'the agriculturist's' finances during the depression crisis was that undertaken in Hanthawaddy between November 1930 and October 1933 as part of the third revision of the district's revenue settlement. These data are not without their problems.

The Hanthawaddy settlement report contains two sets of statistical data which may be of value in this context. ${ }^{44}$ The first is a calculation of 'cost of living' - in fact core expenditure on food, clothing, and shelter-per household. The calculation is based on a survey of well over a thousand households - the households of landowners and tenants. This material has three weaknesses. The settlement report cheerfully warns that 'no great reliance should be placed on the

${ }^{44}$ Report on the Third Revision Settlement of the Hanthawaddy District of Lower Burma, 1930-33 (Rangoon: Government Printing and Stationery, 1934), pp. 11, 13, 64-5, 169 . 
amounts shown', for they had been calculated from accounts of expenditures 'which the cultivator repeats largely from memory'. ${ }^{45}$ Second, the average area of paddy land worked by the households surveyed was 38.33 acres, which suggests that the survey was skewed towards the more substantial agriculturists. ${ }^{46}$ And finally, to restate an earlier point, an average figure drawn from a thousand and more observations obviously says nothing about distribution or range. ${ }^{47} \mathrm{But}$ for what it is worth, the figure calculated for living costs was Rs 263 per household or, with the average household comprising four adults and two children, Rs 44 per head.

The second set of statistical data is a calculation of the costs of rice cultivation that includes 'everything possible of capital, materials and labour'. A figure is given for each of the district's nineteen tracts, and they range from Rs $12.5^{\circ}$ to $\operatorname{Rs} 16.5^{\circ}$ per acre. If the average area worked was, as above, 38.33 acres, cultivation costs per household would lie between Rs 479 and Rs 632: for the ownercultivator in Hanthawaddy, working on average 14.30 acres (see fn. 46), cultivation costs would be between Rs 179 and Rs 236. Two further calculations are worth noting. The average amount of temporary debt per household-debts contracted and repaid within twelve months-is given as Rs 137, of permanent debt, Rs 676: in terms of debt per acre (again assuming the household works on average 38.33 acres), Rs 3.6o and Rs 17.60. And finally, average expenditure in interest payments per household is given as Rs 38.00 , that is Rs 1.00 per acre and Rs 6.3o per head.

These calculations provide a valuable perspective on the figures for tax demands, remissions, collections, and outstandings during the depression crisis. The capitation tax was levied at Rs 5 for a married man before the crisis, Rs $3^{-12}$ in 1931/32. For the average household surveyed during the Hanthawaddy settlement (with four adults, and assuming two were male), the annual capitation tax bill would therefore have been Rs 10 , then reduced to Rs $7-8$. That was a very modest charge when set against, for example, living costs of Rs 263, cultivation costs of at least Rs 479, or even expenditure in interest

${ }^{45}$ Ibid., p. 11. The report continued, with some bitterness: 'It is doubtful if the results of this enquiry are commensurate with the time and labour spent on it.'

${ }^{46}$ At this time, the average area worked by an owner-cultivator in Hanthawaddy was 14.30 acres, by a tenant, 31.06 acres: ibid., p. 32 .

47 The figure given below compounds this weakness, for it is the average for the district. The settlement report also gives the figure for each of the district's nineteen tracts. 
payments of Rs 38. At the same time, the Hanthawaddy households were the households of landowners and tenants, and, it was suggested above, more substantial owners and tenants at that. In other words, for poorer agriculturists - the marginal owner-cultivator and, even more so, the landless labourer-the capitation tax would have been a more severe burden, obviously so. Just how much more severe can be judged from the observation that the cost of food and shelter for a labourer at the beginning of the 1930 s was around Rs 5 a month. ${ }^{48}$ Therefore in the crisis year 1930/31, for example, the married labourer paid in capitation tax the equivalent of one month's food and shelter: reduction of the rate to Rs $3^{-12}$ in $1931 / 32$ and to Rs 4 from 1932/33 would have provided a significant measure of relief. But there is a final important consideration. By no means every person in Lower Burma paid the capitation tax. As noted earlier, not only was it levied only on males between the ages of eighteen and sixty but certain important groups within that category-government officials, school teachers, and monks-were exempt. Even so, the proportion of the population assessed for the tax in the early 1930s appears to have been markedly low, particularly when it is noted that, given the low life-expectancy of that time, relatively few people would have been over sixty. In 1934/35 the proportion was between 17 per cent and 23 per cent in the different rice districts. ${ }^{49}$ And within those low proportions-to bring back an earlier pointmany would certainly not have struggled to pay.

For landowners, the big tax was undoubtedly the land revenue, which, of course, only they paid. Just how serious a burden it could be is suggested by a further set of figures in the Hanthawaddy settlement report. These show the average amount of land revenue paid per matured acre as Rs 3.70 in $1930 / 31$, and falling to Rs 3.12 in $1932 / 33 \cdot{ }^{50}$ Therefore, for the average Hanthawaddy household, assuming again that it worked 38.33 acres, the land revenue bill in 1930/31 would have been Rs 142- the equivalent of more than half the household's outlay, Rs 263 , in living costs. Looked at another way, a land revenue cost of Rs 3.70 an acre compares with cultivation costs per acre-for capital, materials, and labour-of between Rs $12.5^{\mathrm{O}}$ and $\mathrm{Rs} 16.5^{\mathrm{O}}$. From both perspectives, the land revenue is clearly seen as a major charge on the landowner's cash resources.

\footnotetext{
${ }^{48}$ Furnivall, Introduction to the Political Economy of Burma, p. 76.

${ }^{49}$ RLRAB, I934/35, p. 9 .

${ }^{50}$ Report on the Third Revision Settlement of the Hanthawaddy District of Lower Burma, I930-33, p. 139 .
} 
It is hardly surprising that, from the onset of the economic crisis, landowners, in large organized meetings, called for drastic cuts in land revenue rates. ${ }^{51}$

Undoubtedly they would be disappointed by the administration's response. The fall in the amount of land revenue paid per acre in Hanthawaddy between 1930/31 and 1932/33, noted above, was a fall of only 15.7 per cent. The fall in land revenue collections in Tharrawaddy, Hanthawaddy, and Pegu (calculated above from Tables 1-3) was more severe- 43.6 per cent in Pegu. But none of these measures comes close to matching the fall in the price of rice during the economic crisis. ${ }^{52}$ In other words, despite the administration's concessions, the real claim of the land revenue on the landowner, already considerable, rose.

\section{IV}

This paper has provided two firm conclusions. During the economic crisis of the early 1930 s, the British administration in Burma agreed substantial cuts in rates for both the land revenue and the capitation tax and considerably enhanced remissions. But it did so after the economic crisis struck the Burma delta with full force-although it might be felt that the suddenness with which rice prices gave way over the final months of 1930 meant that the administration simply had insufficient time to act in advance.

It is far more difficult to assess the extent to which the administration's measures provided relief through the economic crisis for the rice delta's agriculturists. However, there are grounds for arguing that the impact of the reductions in the rate of capitation tax and the increased remissions was limited. Only around one person in five-20.16 per cent of the population in the Pegu and Irrawaddy Divisions in $1930 / 31^{53}$ - was assessed for the tax. And among the assessees, those with even the most modest resources-the tenant

\footnotetext{
${ }^{51}$ See, for example, $R G W B, 24$ November 1930, p. 8.

${ }^{52}$ The extent of that fall can be indicated in a number of ways. In May 1931 the administration reported that the price of paddy had fallen to about Rs $6_{5}$ per one hundred baskets from an average 'in recent years' of Rs $15^{\circ}$ or more: Secretary, Finance Department, Government of Burma to Secretary to the Government of India, Finance Department, 7 May 1931. NAI, Finance, 1 $7 / 67,1932$. The price was to fall considerably further.

${ }^{53}$ RLRAB, I93o/ 3 I, p. 37.
} 
working a few hectares, the marginal owner-cultivator-are unlikely to have found the capitation tax a serious burden, even before the rate was cut. The agriculturist most threatened by the tax, and therefore most relieved by the cuts and increased remissions, was the landless labourer, a class that must include the large number of Indian migrant labourers who found work in the rice delta. ${ }^{54}$ The impact of the reductions in land revenue rates and the increased remissions was similarly limited. Only those who owned land drew direct relief: and that relief, if the figures above are a secure indication, was substantially less than the fall in the price of rice. But during the economic crisis of the early 1930s, the population of the Burma rice delta had access to or had themselves developed further mechanisms to mitigate the impact of the collapse in the rice pricean expansion in rice production and sales to compensate for the fall in price; a decline in the prices of essential items of consumption, including, notably, that of imported textiles; and defaulting on loans. These further mechanisms for survival will be the focus of another paper.

${ }^{54}$ If the capitation tax drew hostility from a wider range of the rural population, this was perhaps due in part to its obvious inequity. Moreover it is quite possible that many who could pay the tax with ease were nevertheless very hostile to it on political grounds. Michael Adas notes that 'the Burmans had traditionally regarded the payment of the head tax as an acknowledgement of the legitimacy of the government that collected it': Prophets of Rebellion, p. 74 . 